\title{
Streptococcus bovis/gallolyticus Induce the Development of Colorectal Cancer
}

\author{
A.S. Abdulamir ${ }^{1,2}$, R.R. Hafidh ${ }^{1,3}$ and F.Abu Bakar ${ }^{1}$ \\ ${ }^{1}$ Institute of Bioscience, University Putra Malaysia, Serdang, Selangor, \\ ${ }^{2}$ Microbiology Department, College of Medicine, Alnahrain University PO, Baghdad, \\ ${ }^{3}$ Microbiology Department, College of Medicine, Baghdad University, \\ ${ }^{1}$ Malaysia \\ 2,3 Iraq
}

\section{Introduction}

The role, of microbial agents and the infection of the intestinal mucosa in the carcinogenesis, or the development of colorectal cancer (CRC) is one of the hot topics in the field of CRC where much research has been done. However, this topic has long been underestimated by most of the related books. This chapter is intended to cover the relationship of CRC development with bacteria implicated in the development of CRC such as S. bovis, S. gallolyticus, S. equines, S. infantarius, E .coli, C. difficile...etc. However, S. gallolyticus and S. bovis will be discussed thoroughly in this chapter as they are considered the prototype for intestinal microorganisms related to CRC and colorectal premalignant lesions.

Studying CRC association with infection of intestinal mucosa is not complete without studying the underlying mechanisms. There is compelling evidence that CRC is largely affected by the status of intestinal bioflora. CRC has been found to be affected by certain microbial agents that have particular characteristics capable of inducing dysplastic changes in intestinal mucosa. However, the underlying mechanisms of the association of implicated infective agents with CRC development are yet not clear. In addition, the role of oncogenic factors, cell growth factors, and pro-inflammatory cytokines in the association of bacterial infection in intestinal mucosa with CRC has not yet been clarified well. Therefore, the current chapter attempts to scrutinize the nature and the underlying mechanisms of the association of infective agents represented by S. bovis/gallolyticus with CRC. Nevertheless, the association of $S$. bovis/gallolyticus with CRC is still under controversy regarding whether the bacterial infection of intestine, along with associated bacteremia/endocarditis, is a consequence or the etiological factor of CRC. Hence, this chapter also attempts to explore the facts available in the field to assess which scenario is more favorable for the association of S. bovis/gallolyticus with CRC namely, the consequence or the etiology scenario.

One of the bacterial agents that have been most associated with cancer is Streptococcus bovis (S. bovis). S. bovis has been shown to be important in human health because 25 to $80 \%$ of patients with $S$. bovis bacteremia had also colorectal tumor, and the incidence of association of colonic neoplasia with S. bovis endocarditis was shown to be 18 to $62 \%$ (Gupta et al., 2009; Kok et al., 2007; Leport et al., 1987; Malkin et al., 2008; Reynolds et al., 1983; Wilson et al., 
1981; Zarkin et al., 1990). Later, it was shown that a new species resembling S. bovis is actually most implicated in CRC development; S. bovis infecting human intestine has been named as S. gallolyticus (Osawa et al., 1995). More precisely, S. bovis biotype I and II/2 isolates were shown to be S. gallolyticus (Devriese et al., 1998). Accordingly, S. bovis biotype I was replaced by $S$. gallolyticus subspecies gallolyticus and biotype II/2 was replaced by $S$. gallolyticus subspecies pasterianus and S. gallolyticus subspecies macedonicus (Schlegel et al., 2003). S. gallolyticus subspecies gallolyticus, rather than other related taxa, have been found to be constantly associated with underlying colorectal cancer.

\section{The association of colorectal cancer with S. bovis/gallolyticus bacteremia/endocarditis}

S. bovis, has long been linked to the development of CRC. However, the extent, nature, and basis of this association are still not completely understood. S. bovis/gallolyticus became important in human health since it was shown that 25 to $80 \%$ of patients who presented $S$. bovis/gallolyticus bacteremia had also a colorectal tumor and the incidence of association of colonic neoplasia with S. bovis/gallolyticus endocaditis was shown to be 18 to $62 \%$ (Gupta et al., 2009; Kok et al., 2007; Leport et al., 1987; Malkin et al., 2008; Murray \& Roberts, 1978; Reynolds et al., 1983; Wilson et al., 1981; Zarkin et al., 1990). The knowledge that there is an association between endocarditis from S. bovis/gallolyticus and carcinoma of the colon has important clinical implications (Boleij et al., 2009a; Kok et al., 2007). The majority of the studies that found clues on the association of S. bovis/gallolyticus with CRC was in Europe and North America. Actually, it is true that the association of S. bovis/gallolyticus bacteremia with colorectal cancer has been found variable among different geographical and ethnic groups (Boleij et al., 2009a), but this association is not restricted to certain geographical region. A recent study done in Malaysia found that $48.6 \%$ of $S$. bovis isolates was found in patients with colonic polyps, adenocarcinomas, inflammatory bowel diseases. It was also found that colorectal cancer incidence was $24.7 \%$, adenocarinomas accounting for $51 \%$ with the highest incidence in the sigmoid part of the colon(Al-Jashamy et al., 2010). This study indicates a strong relationship between S. bovis/gallolyticus and colonic premalignant as well as malignant lesions in a geographical region that was considered of low incidence for CRC cases associated with bacterial infections. Moreover, an epidemiological study conducted in Hong Kong on S. bovis bacteremia and its relation to colorectal cancer, confirmed the association of $S$. bovis/gallolyticus with CRC and found that $S$. bovis biotype II/2 is the dominant in Hong Kong rather than biotype I (S. gallolyticus) which is dominant in Western countries (Lee et al., 2003).

Thorough studies on $S$. bovis have shown that associations between $S$. bovis bacteraemia and carcinoma of the colon and infective endocarditis were biotype-specific. It was shown that there is $94 \%$ association between $S$. bovis biotype I bacteraemia and infective endocarditis and $71 \%$ association between $S$. bovis biotype I bacteraemia and colonic carcinoma. On the other hand, it is only $18 \%$ association between S. bovis biotype II bacteraemia and infective endocarditis and $17 \%$ association between S. bovis biotype II bacteraemia and colonic carcinoma (Murray \& Baron, 2007). Following the description of S. gallolyticus, Devriese team used whole-cell protein analysis to show that all six bacterial isolates studied, which were derived from patients with endocarditis and identified by conventional techniques as $S$. bovis, were in fact $S$. gallolyticus. Therefore, they suggested that $S$. gallolyticus is more likely to be involved in human infections than is S. bovis (Devriese et al., 1998). 
The underlying mechanisms for the association of CRC with S. bovis/gallolyticus bacteremia/endocarditis have been obscure for a long time. The possible reason behind that, maybe, S. bovis/gallolyticus is a member of intestinal flora in 2.5 to $15 \%$ of individuals which usually make scientists counteract any malicious role of this bacteria (Burns et al., 1985; Murray \& Roberts, 1978). It was conceived in the beginning that the ulceration of neoplastic lesions might form a pathway for the microorganism to enter the bloodstream (Gupta et al., 2009). However, the latter scenario of bacterial access into the circulation does not explain the cases of patients with infectious endocarditis and non-ulcerated colonic polyps (Cutait et al., 1988). Furthermore, colonic neoplasia may arise years after the presentation of the condition of bacterial bacteremia or infectious endocarditis (Fagundes et al., 2000; Zarkin et al., 1990). For this reason, patients with infectious endocarditis and normal colonoscopy may be included in the group who present risk for developing colonic cancer because of the late appearance of such lesions after the infectious episode of S. bovis/gallolyticus (Fagundes et al., 2000). Moreover, in supporting the second scenario, it has been shown that the relative risk of developing infectious endocarditis from S. bovis/gallolyticus in the presence of carcinoma of the colon is merely 3 to $6 \%$ (Bisno \& 12.ed. New York: , 1991) while 60 to $75 \%$ of patients with endocarditis by $S$. bovis/gallolyticus simultaneously present malignant gastrointestinal disease that was not previously diagnosed (Grinberg et al., 1990).

\section{The association of premalignant colorectal lesions with S. bovis/gallolyticus}

There is a high incidence of colorectal cancer in individuals with polyps; about $90 \%$ of preinvasive neoplastic lesions of the colorectum are polyps or polyp precursors, namely aberrant crypt foci (Nielsen et al., 2007). Neoplastic polyps are often referred to more specifically as adenomas or adenomatous polyps (Srivastava et al., 2001). Adenomatous polyps are considered as good and few surrogate end point markers for colorectal cancer (Kelly et al., 1989; Nielsen et al., 2007).

It would be of interest to substantiate any relationship between bacterial colonic carriage, colonic polyps and the type of polyp and its malignant potential (Boleij et al., 2009a; Schlegel et al., 2003). Contrary to the more commonly reported association between $S$. bovis/gallolyticus bacteremia and colorectal cancer, a link to pre-neoplastic adenomatous polyps was less frequently reported (Burns et al., 1985; Ellmerich et al., 2000a). Nevertheless, the relationship between colorectal bacterial infection and the progressive development of malignant disease in pre-neoplastic adenomatous polyps was supported by recent reports (Abdulamir et al., 2009; Kahveci et al., 2010; Murinello et al., 2006). Interestingly, benign lesions (diverticulosis, inflammatory bowel disease, cecal volvulus, perirectal abscess hemorrhoids, benign polyps) were found to be mildly associated with intestinal bacterial infections such as S. bovis/gallolyticus while a strong relationship between more malignant diseases of the colon (cancer and neoplastic polyps) and S. bovis/gallolyticus was found (Abdulamir et al., 2009; Burns et al., 1985; Klein et al., 1979; Nielsen et al., 2007; Reynolds et al., 1983; Smaali et al., 2008). It was also revealed that S. bovis/gallolyticus septicemia and/or endocarditis is selectively related to the presence of villous or tubulovillous adenomas in the large intestine (Fagundes et al., 2000; Smaali et al., 2008). In fact, Villous and tubulovillous adenomas, which have risk of malignant transformation about $15-25 \%$, were found to be associated with S. bovis/gallolyticus bacteria more often than other types of adenomas (Bond, 2005). For example, Hoen team performed a case-control study on subjects underwent 
colonoscopy comparing between patients with S. bovis/gallolyticus endocarditis and sex- and age- matched unaffected patients. This study showed that colonic adenomatous polyps were present in twice as many cases as controls (15 of 32 vs 15 of 64), and colorectal cancer was present approximately 3 times as often (3 of 32 vs 2 of 64) (Hoen et al., 1994). However, surprisingly, another study (Devis et al., 1989) found that the association between $S$. bovis/gallolyticus and adenoma was more evident than that with colorectal cancer; they reported that $36 \%$ of positive blood cultures of S. bovis/gallolyticus were found in proliferative lesions (15\% of cancers and $21 \%$ of adenomas). A recent study (Abdulamir et al., 2009) supported this concept showing that the level of S. bovis/gallolyticus IgG antibodies in adenoma patients is much higher than in both colorectal cancer patients and control subjects. However, other reports did not reveal the same thing. (Burns et al., 1985) stated that the incidence of $S$. bovis/gallolyticus carriage in all colons with polyps was intermediary between normal colons and colons with carcinoma although the difference did not achieve statistical significance.

Regarding the fecal carriage of S. bovis/gallolyticus, (Burns et al., 1985) demonstrated that highly premalignant polyps were found to be more often associated with $S$. bovis/gallolyticus carriage than were benign polyps. A clue for the active role of intestinal bacteria in the development of CRC, S. bovis/gallolyticus endocarditis, rather than other members of group D Streptococcus, showed special predilection to colonic lesions. It was found that of 77 infections with group D Streptococcus endocarditis, colonic polyps and colonic carcinoma were significantly more frequent in the S. bovis/gallolyticus group (67 and 18\%) respectively than in the Enterococcus group (21 and 2\%) respectively (Leport et al., 1987). This indicates that certain bacteria have role in the etiology of CRC development from premalignant poly lesions.

The remarkable association between adenomatous polyps and S. bovis/gallolyticus seems to be of importance due to the compelling evidence that colon cancer progresses from normal tissue to adenoma and then to carcinoma through an accumulation of genetic alterations (Baron \& Sandler, 2000). Although ulceration of the neoplastic lesion might form a pathway for the S. bovis/gallolyticus to enter the bloodstream (Gupta et al., 2009), the association of S. bovis/gallolyticus bacteremia with non-ulcerated colonic polyps indicates an etiological/promoter role of these bacteria in polyps progression (Cutait et al., 1988; Konda \& Duffy, 2008). The possibility of $S$. bovis/gallolyticus to act as a promoter for the preneoplastic lesions is worthy to be considered. A remarkable study supported this hypothesis using rats treated with $S$. bovis wall extracted antigens (WEA), rats treated with a chemical carcinogen, rats treated with both WEA and chemical carcinogen, and untreated rats. All groups of rats did not develop hyperplastic colonic crypts except for the group treated with both WEA and the chemical carcinogen; about $50 \%$ rats of this group developed neoplastic lesions (Ellmerich et al., 2000a). This indicated that $S$. bovis bacteria might exert their pathological activity in the colonic mucosa only when preneoplastic lesions are established. Another model supporting the promoter effect of S. bovis/gallolyticus, $\mathrm{H}$. pylori infection and subsequent inflammation seem most likely to be promoters in the multistep development of carcinoma (from chronic gastritis to atrophy, intestinal metaplasia, dysplasia, and, ultimately, cancer) rather than the causative agents (Leung, 2006). Therefore, the association of S. bovis/gallolyticus in etiology and/or acceleration of the transformation of aberrant crypts to adenoma and to cancer is now being reconsidered. 
Accordingly, the knowledge of association of colorectal adenoma with S. bovis/gallolyticus has important clinical implications. If the lesion can be discovered at an early stage, curative resection may become possible (Waisberg et al., 2002). Thus, bacteremia due to $S$. bovis/gallolyticus should prompt rigorous investigation to exclude both endocarditis and tumors of the large bowel (Beeching et al., 1985; Konda \& Duffy, 2008). Therefore, it was concluded that the discovery of a malignant or premalignant proliferative lesion in one third of the cases justifies the exploration of the colon by barium enema and/or colonoscopy in the case of S. bovis/gallolyticus septicemia (Beeching et al., 1985; Konda \& Duffy, 2008). This would empirically aid for the early detection of adenoma in the gastrointestinal tract before its progression to cancer.

\section{The proposed mechanisms for the development of colorectal cancer by S. bovis/gallolyticus}

Chronic inflammation is associated with malignant changes. Host genetic polymorphisms of the adaptive and innate immune response play an important role in bacteria-induced cancer formation (El-Omar, 2006; Hou et al., 2007; Karin \& Greten, 2005). Therefore, studying the immunological responses to chronic bacterial infections is likely to yield important clues on both the mechanisms of persistent infection and the relationship between inflammation and cancer formation (Ernst et al., 2006; Monack et al., 2004). Clinical studies have shown that the use of non-steroidal anti-inflammatory drugs is associated with a reduced risk of gastric cancer (Dai \& Wang, 2006). However, bacteria implicated in carcinogenesis, like $S$. bovis/gallolyticus, might use several mechanisms for carcinogenesis such as the colonization of epithelial surfaces and the use of virulence factors to chronically affect host cell cycle control, apoptosis, cell junction integrity or cell polarity ((Vogelmann \& Amieva, 2007).

\subsection{Clues for etiological role}

The big question is whether bacteria play an etiological role in the carcinoma of colon or it is merely marker of the disease. There are many clues collectively provide evidence for the etiological role of bacteria in colon cancer development. The striking association between bacteremia caused by S. bovis biotype I and both colonic neoplasia (71\%) and bacterial endocarditis (94\%), rather than bacteremia caused by closely related organisms such as $S$. bovis variant and S. salivarius, suggests the possibility of specific bacterium-host interactions (Ruoff et al., 1989). Moreover, the appearance of new colonic lesions 2-4 after the incidence of S. bovis/gallolyticus bacteremia/endocarditis, provides more evidence that $S$. bovis/gallolyticus is not merely a consequence of the tumor lesion (Wentling et al., 2006). In terms of pathogenesis, as S. bovis/gallolyticus is a transient normal flora in the gut, researchers have postulated that the increased bacterial load of S. bovis/gallolyticus in colon might be responsible for its association with colon cancer. Several studies have shown that increased stool carriage of $S$. bovis/gallolyticus is particularly found in patients with inflammatory bowel diseases or malignant/premalignant lesions of the colon while $S$. bovis/gallolyticus bacteria were rarely isolated from normal subjects (Teitelbaum \& Triantafyllopoulou, 2006). Another clue supporting the etiological role of S. bovis/gallolyticus, patients diagnosed with colon cancer have only 3-6\% chance to develop S. bovis/gallolyticus endocarditis (zur Hausen, 2006), which is far lower than the percentage of the detection of 
colorectal cancer in patients with $S$. bovis/gallolyticus bacteremia/endocarditis, which his more than $70 \%$.

\subsection{Mechanisms of the proposed etiological role of S. bovis/gallolyticus in the development of colorectal cancer \\ 4.2.1 Selective adherence to intestinal tumor cells}

Some bacteria such as S. bovis/gallolyticus are frequent colonizers of the intestinal tract, which can also cause endocarditis. However, their ability to adhere to and colonize host tissues is largely unknown. It was found that $S$. bovis/gallolyticus bacteria possess collagenbinding proteins and pili that are responsible for adhesion to colorectal mucosa as well as to endocardium (Sillanpaa et al., 2009). On the other hand, another study (Boleij et al., 2009b) found a histone-like protein A on the surface of S. bovis/gallolyticus able to bind heparan sulfate proteoglycans at the colon tumor cell surface during the first stages of infection; this cell surface protein in S. gallolyticus acts as one of the main heparin-binding proteins that is largely responsible for bacteria selective adhesive potential as well as entry to the blood circulation. Another study assessing 17 endocarditis-derived human isolates, identified $15 \mathrm{~S}$. gallolyticus subspecies gallolyticus, one S. gallolyticus subspecies pasteurianus (biotype II/2) and one $S$. infantarius subspecies coli (biotype II/1) for their in vitro adherence to components of the extracellular matrix; this study provided evidence that $S$. gallolyticus subspecies gallolyticus bacteria possess very efficient adherence characteristics to the host extracellular matrix; this bacteria showed powerful adherence to collagen type I and type IV, fibrinogen, collagen type V, and fibronectin (Sillanpaa et al., 2008). These adherence merits render these bacteria successful colonizers in both intestinal and cardiac tissues which might explain the association between S. bovis/gallolyticus endocarditis and intestinal lesions.

\subsubsection{Changing the intestinal bacterial flora and alterations in the local vascular attributes}

Increased incidence of hepatic dysfunction has been reported in patients with bacterial infectious endocarditis (Fagundes et al., 2000). It has been speculated that $S$. bovis/gallolyticus affects portal circulation through bacterial translocation, thereby determining hepatic alterations. Modifications in the hepatic secretion of bile salts and the production of immunoglobulins contribute towards increasing the participation of S. bovis/gallolyticus in abnormal changes in the bacterial flora of the colonic lumen which might then promote carcinogenesis of the intestinal mucosa (Beeching et al., 1985; Gupta et al., 2009).

It has been suggested that alterations in local conditions and disruption of capillary channels at the site of neoplasm allowed S. bovis/gallolyticus to proliferate and gain entry into blood stream (Biarc et al., 2004; Ellmerich et al., 2000a; Nguyen et al., 2006). The local action of cytokines or of chemical mediators able to promote vasodilatation and the enhancement of capillary permeability, may support the bacterial entry at tumor sites, and increase bacterial adherence to various cells (Biarc et al., 2004; Ellmerich et al., 2000b).

\subsubsection{Promoting/propagating effect on preneoplastic lesions and inflammation-driven carcinogenesis}

A series of interesting experiments was conducted for investigating the role of $S$. bovis/gallolyticus in the initiation and development of colorectal cancer. Chemical carcinomas 
were induced by giving adult rats intraperitonial injections of azoxymethane $(15 \mathrm{mg} / \mathrm{kg}$ body weight) once per week for 2 weeks. Fifteen days (week 4) after the last injection of the carcinogen, the rats received, by gavage twice per week during 5 weeks, either $S$. bovis (1010 bacteria) or wall-extracted antigens (WEAs) $(100 \mu \mathrm{g})$. One week after the last gavage (week $10)$, it was found that administration of either S. bovis or its antigens promoted the progression of preneoplastic lesions into neoplastic lesions through the increased formation of hyperproliferative aberrant colonic crypts, which enhanced the expression of proliferation markers and increased the production of IL-8 in the colonic mucosa (Biarc et al., 2004; Ellmerich et al., 2000b). Therefore, this study suggests that $S$. bovis/gallolyticus bacteria act as potential promoters of early preneoplastic lesions in the colon of rats, and their cell wall proteins are more potent inducers of neoplastic transformation than the intact bacteria. This study also revealed that the development of colonic adenomas increased remarkably in $50 \%$ of the tested rats and the expression level of proliferation markers, the polyamine content and proliferating cell nuclear antigen was also increased (Biarc et al., 2004; Ellmerich et al., 2000a; Nguyen et al., 2006). This provided extra evidence that $S$. bovis/gallolyticus acts more likely as promoter/propagator of colorectal carcinoma rather than just a consequence of the tumor lesion. These studies might suggest that bacteria, in general, are often not capable to induce cancer without the presence of other predisposing factors for carcinogenesis. In this regard, it was conceived that the transformation process of colorectal tumors associated with S. bovis/gallolyticus is more likely accompanied with long-lasting bacterial promoting/propagating effect along with chronic inflammation status in intestinal mucosa. This conclusion was supported by Balkwill et al. stating that tumor formation might require independent mutations in oncogenic signaling pathways in addition to chronic inflammatory conditions which are needed to promote transformation process (Balkwill et al., 2005).

In vitro experiments showed that the binding of $S$. bovis wall extracted antigens to various cell lines including human colonic cancer cells (Caco-2) stimulated the production of inflammatory cytokines by those cells (Biarc et al., 2004; Nguyen et al., 2006). Earlier it was found that the production of inflammatory cytokines in response to $S$. bovis/gallolyticus, such as TNF- $\alpha$, IL-1B and IL-6, and the chemokine IL-8, were found to contribute to the normal defense mechanisms of the host (Ellmerich et al., 2000b; Travers \& Rosen, 1997) leading to the formation of nitric oxide and free radicals such as superoxide, peroxynitrites, hydroxyl radicals as well as alkylperoxy radicals (Nguyen et al., 2006; Ohshima \& Bartsch, 1994). Owing to their potent mutagenicity, all these molecular species can contribute to the neoplastic processes by modifying cellular DNA. On the other hand, in the colonic mucosa, the production of angiogenic factors, such as IL-8, triggered by S. bovis/gallolyticus antigens may also favor the progression of colon carcinogenesis (Eisma et al., 1999; Ellmerich et al., 2000b; Norrby, 1996). This resembles H. pylori infection for the development of chronic inflammation in the gastric mucosa (Dixon et al., 1996); therefore, it seems that chronic infection and subsequent chronic inflammation are responsible for the maintenance and development of pre-existing neoplastic lesions (Shacter \& Weitzman, 2002).

Moreover, it was found that WEAs of $S$. bovis induced in vitro overexpression of cyclooxygenase-2 (COX-2) (Biarc et al., 2004; Nguyen et al., 2006). COX-2, via prostaglandins, promotes cellular proliferation and angiogenesis and inhibits apoptosis, thus acting as a promoter in the cancer pathway (Tafte \& Ruoff, 2007). It is noteworthy to mention that non-steroidal anti-inflammatory drugs (NSAIDS) were found to decrease the relative risk of gastrointestinal carcinomas and their main target was found to be 
cyclooxygenase 2 (COX-2) that is over-expressed in up to $85 \%$ of colorectal adenocarcinomas (Kargman et al., 1995). Moreover, (Haqqani et al., 2000) revealed that the activation of leukocytes by $S$. bovis/gallolyticus was found to release various other inflammatory mediators (NO, free radicals, peroxynitriles, etc.) which could interfere directly or indirectly with the cell proliferation process. A recent study conducted by our team, S. gallolyticus has shown a specific association with colorectal cancer and colorectal adenoma when compared with the more dominant intestinal bacteria, $B$. fragilis. This provided evidence for a possible important role of $S$. gallolyticus in the carcinogenesis of colorectal cancer from pre-malignant polyps. In addition, it was also found that NF-kB and IL-8 rather than other transformation factors p21, p27 and p53 act as important mediators for the S. gallolyticus-associated transformation of adenoma to carcinoma (Abdulamir et al., 2009). Moreover, it was concluded that NF-KB exerts most probably a promoting carcinogenic effect and IL-8 exerts mainly an angiogenic-based propagating effect on colorectal mucosal cells (Abdulamir et al., 2009). In addition, a more recent study done by our team showed a direct and active role of S. bovis/gallolyticus in colorectal cancer development through inflammation-based sequel of tumor development or propagation via IL-1, COX-2, and IL-8 (Abdulamir et al., 2010). By these studies, a strong relationship was shown to be evident between the proinflammatory potential of $S$. bovis/gallolyticus bacteria and their carcinogenic properties confirming the linkage between inflammation and colon carcinogenesis.

In the presence of WEAs proteins of S. bovis/gallolyticus, Caco-2 cells exhibited enhanced phosphorylation of 3 classes of mitogen activated protein kinases (MAPKs) (Biarc et al., 2004). Several reports showed that MAPKs activation stimulates cells to undergo DNA synthesis and cellular uncontrolled proliferation (Hirata et al., 2001; Ihler, 1996; Smith \& Lawson, 2001). Therefore S. bovis/gallolyticus proteins could promote cell proliferation by triggering MAPKs which might increase the incidence of cell transformation and the rate of genetic mutations. Furthermore MAPKs, particularly p38 MAPK, can induce COX-2 which is an important factor in tumorogenesis (Lasa et al., 2002; Wang \& Dubois, 2010) and upregulate the expression of NFkB which is considered the central link between inflammation and carcinogenesis (Karin \& Greten, 2005). Accordingly, the pro-inflammatory potential of S. bovis/gallolyticus proteins and their pro-carcinogenic properties as well as the chronic inflammation and the leucocytic recruitment driven by S. bovis/gallolyticus provide strong evidence on the possible causal link between S. bovis/gallolyticus inflammation and colonic carcinogenesis. Therefore, the above data support the hypothesis that colonic bacteria can contribute to cancer development particularly via chronic infection/inflammation where bacterial components may interfere with cell function for long time (Biarc et al., 2004; Wang \& Dubois, 2010).

\section{Selective colonization of S. bovis/gallolyticus in colorectal mucosa}

The association of bacteria with colorectal cancer has always been described through the incidence of S. bovis/gallolyticus bacteremia and/or endocarditis (Leport et al., 1987; Murray \& Roberts, 1978; Reynolds et al., 1983; Wilson et al., 1981; Zarkin et al., 1990). On the other hand, little bacteriological research has been done on elucidating the colonization of $S$. bovis/gallolyticus in tumor lesions of colorectal cancer in order to confirm or refute, on solid bases, the direct link between colorectal cancer and S. bovis/gallolyticus (Norfleet \& Mitchell, 1993; Potter et al., 1998). A recent study of by our team was conducted to assess the colonization of S. bovis/gallolyticus bacteria in colon by detecting S. bovis/gallolyticus DNA in 
colorectal cancer tumors using advanced molecular assays (Abdulamir et al., 2010). In Abdulamir et al. study, S. bovis/gallolyticus-specific primers and probes were used in PCR and in situ hybridization (ISH) assays, respectively, to detect $S$. bovis/gallolyticus DNA from feces, tumor mucosal surfaces, and from the inside of tumor lesions. In addition, bacteriological isolation of $S$. bovis/gallolyticus was conducted to isolate S. bovis/gallolyticus cells from feces, tumor mucosal surfaces, and from the inside of tumor lesions. In this study, S. bovis/gallolyticus was successfully isolated, via bacteriological assays, from tumorous and non-tumorous tissues, of colorectal cancer patients with bacteremia, $20.5 \%$ and $17.3 \%$, and of colorectal cancer patients without bacteremia, $12.8 \%$ and $11.5 \%$, respectively while only $2 \%$ of control tissues revealed colonization of S. bovis/gallolyticus.

On the other hand, the positive detection of S. bovis/gallolyticus DNA, via PCR, in tumorous and non-tumorous tissues of colorectal cancer patients with bacteremia, 48.7 and $35.9 \%$, and without bacteremia, 32.7 and $23 \%$, respectively, was remarkably higher than that in control tissues, $4 \%$. And the positive detection of S. bovis/gallolyticus DNA, via ISH, in tumorous and non-tumorous tissues of colorectal cancer patients with bacteremia, 46.1 and $30.7 \%$, and without bacteremia 28.8 and $17.3 \%$, respectively was remarkably higher than that in control tissues, $2 \%$. In addition, by using absolute quantitative PCR for S. bovis/gallolyticus DNA, the S. bovis/gallolyticus count, in terms of copy number $(\mathrm{CN})$, in tumorous and non-tumorous tissues of colorectal cancer patients with bacteremia, 2.96-4.72 and 1.29-2.81 $\log _{10} \mathrm{CN} / \mathrm{g}$, respectively, and colorectal cancer patients without bacteremia, 2.16-2.92 and 0.67-2.07 $\log _{10}$ $\mathrm{CN} / \mathrm{g}$, respectively, showed significantly higher level of colonization in tumorous than in non-tumorous tissues and in colorectal cancer patients with bacteremia than in colorectal cancer patients without bacteremia. Accordingly, this study provided several new observations. First, S. bovis/gallolyticus colonizes selectively tumorous tissues of colorectal cancer patients rather than normal mucosal tissues. Second, the colonization of $S$. bovis/gallolyticus is mainly found inside tumor lesions rather than on mucosal surfaces of tumors. Third, the titer of the colonizing S. bovis/gallolyticus bacteria in colorectal cancer patients with bacteremia/endocarditis was much higher than in patients without bacteremia/endocarditis; this explains why some colorectal cancer patients develop concomitant bacteremia of $S$. bovis/endocarditis while others do not. Actually, the newly discovered selective colonization of $S$. bovis/gallolyticus explains the conclusions of an earlier report (Tjalsma et al., 2006) stating that colonic lesions provide a suitable microenvironment for S. bovis/gallolyticus colonization resulting in silent tumor-associated infections that only become apparent when cancer patients become immunocompromised, as in bacteraemia, or have coincidental cardiac valve lesions and develop endocarditis.

\section{Using S. bovis/gallolyticus in the early detection of colorectal tumors}

For a long time, it has been conceived that there is a need to establish a good screening test for colonic cancer patients, particularly a test which could detect early lesions. It has been suggested that the presence of antibodies to certain bacterial antigens or the presence of certain bacterial antigens in the bloodstream may act as markers for carcinogenesis of the colon (Beeching et al., 1985; Potter et al., 1998). The serology-based detection of colorectal cancer has advantage on other tests such as fecal occult blood which is neither sensitive nor specific or carcinoembryonic antigen which is regularly detectable in only advanced diseases (Tafte \& Ruoff, 2007). Darjee and Gibb stated that it might be possible to develop a 
test to screen patients for the presence of colonic cancer by measuring IgG antibody titer of S. bovis/gallolyticus (Darjee \& Gibb, 1993). Hence, since the association between slow evolving bacterial inflammation and colorectal cancer takes long time, it is prudent to seek specifically for IgG antibodies. Furthermore, IgG antibodies reflect an image of the past and the chronic presence of $S$. bovis/gallolyticus antigens in the circulation.

Some studies showed the possibility of constructing a serology test for the successful detection of colonic cancer based on the detection of antibody to S. bovis/gallolyticus or Enterococcus faecalis (Abdulamir et al., 2009; Groves, 1997). Therefore, a simple ELISA test with no more than $2 \mathrm{ml}$ of patient's blood might be a good candidate for screening high risk individuals for the presence of premalignant neoplastic polyps, adenomas, and cancers. However, some other studies of antibody response to $S$. bovis/gallolyticus and other streptococci have found that antibody is detectable in endocarditis but not in either clinically insignificant bacteremias (Burnie et al., 1987), or colonic cancers ((Kaplan et al., 1983) by using immunoblotting, immunoflourescence and other techniques. In a recent study of our team (Abdulamir et al., 2009), the serum level of IgG antibodies against S. gallolyticus subspecies gallolyticus antigens adsorbed on solid phase of ELISA was found to be significantly higher in colorectal cancer patients than in control subjects. This is in full agreement with the study of (Darjee \& Gibb, 1993) who showed that patients with colonic cancer had higher median IgG antibody titers to $S$. bovis and E. faecalis preparations than did the control samples. Accordingly, the applicability of using ELISA as a cheap and effective assay for the early detection of colorectal cancer using IgG antibodies against $S$. bovis/gallolyticus has been tested and proven (Abdulamir et al., 2009). Therefore, the early detection of colorectal cancer using simple means of testing opens doors to monitor high risk groups of colorectal cancer more efficiently.

\section{Conclusions}

Colorectal tumors, adenoma or carcinoma, are associated remarkably with bacterial infections of intestine. The manifestation of this association is usually observed as concurrent bacteremia or endocarditis of S. bovis/gallolyticus. The association of $S$. bovis/gallolyticus bacteria with colorectal cancer is more likely etiological in nature rather than a consequence of the disease. The proposed etiological role of $S$. bovis/gallolyticus in the development of colorectal cancer might be attributed to many factors including selective adhesion potential of $S$. bovis/gallolyticus to tumor tissues, the selective colonization of $S$. bovis/gallolyticus inside tumor tissues, the suitable microenvironment of tumors for $S$. bovis/gallolyticus proliferation, the local disruption of tumor tissues and capillaries which allow the entry of $S$. bovis/gallolyticus into blood circulation leading to bacteremia and endocarditis, and the bacterially-induced cytokines and transcriptional factors, such as IL-1, IFN- $\gamma$, IL-8, and NFkB, which induce and propagate the chronic inflammatory environment which promote/propagate premaligant intestinal lesions to malignant ones. This is a very important role of S. bovis/gallolyticus in the carcinogenesis of colorectal tissues since the majority of cases of colorectal cancer are sporadic cancers arising through the transformation of normal colorectal tissues to premalignant lesions, adenomas, and finally to malignant tissues. Besides, the early detection of colorectal adenomas or carcinomas via detection of S. bovis/gallolyticus DNA or their specific IgG antibodies might be of high value in screening the high risk groups for colorectal cancer. More in-depth research is needed to 
exploit the association of bacteria with colorectal cancer in terms of early diagnosis of the disease as well as understanding the bacterial carcinogenic potential to determine the appropriate means to prevent and/or treat bacterially-associated cancers.

\section{References}

Abdulamir, A.S., Hafidh, R.R., Bakar, F.A., (2010). Molecular detection, quantification, and isolation of Streptococcus gallolyticus bacteria colonizing colorectal tumors: inflammation-driven potential of carcinogenesis via IL-1, COX-2, and IL-8. Mol Cancer, Vol. 9, No. pp. 249, 1476-4598 (Electronic)1476-4598 (Linking)

Abdulamir, A.S., Hafidh, R.R., Mahdi, L.K., Al-jeboori, T., Abubaker, F., (2009). Investigation into the controversial association of Streptococcus gallolyticus with colorectal cancer and adenoma. BMC Cancer, Vol. 9, No. pp. 403, 1471-2407 (Electronic) 1471-2407 (Linking)

Al-Jashamy, K., Murad, A., Zeehaida, M., Rohaini, M., Hasnan, J., (2010). Prevalence of colorectal cancer associated with Streptococcus bovis among inflammatory bowel and chronic gastrointestinal tract disease patients. Asian Pac J Cancer Prev, Vol. 11, No. 6, pp. 1765-1768, 1513-7368 (Print) 1513-7368 (Linking)

Balkwill, F., Charles, K.A., Mantovani, A., (2005). Smoldering and polarized inflammation in the initiation and promotion of malignant disease. Cancer Cell, Vol. 7, No. 3, pp. 211-217, 1535-6108 (Print) 1535-6108 (Linking)

Baron, J.A., Sandler, R.S., (2000). Nonsteroidal anti-inflammatory drugs and cancer prevention. Annu Rev Med, Vol. 51, No. pp. 511-523, 0066-4219 (Print) 0066-4219 (Linking)

Beeching, N.J., Christmas, T.I., Ellis-Pegler, R.B., Nicholson, G.I., (1985). Streptococcus bovis bacteraemia requires rigorous exclusion of colonic neoplasia and endocarditis. Q J Med, Vol. 56, No. 220, pp. 439-450, 0033-5622 (Print) 0033-5622 (Linking)

Biarc, J., Nguyen, I.S., Pini, A., Gosse, F., Richert, S., Thierse, D., Van Dorsselaer, A., LeizeWagner, E., Raul, F., Klein, J.P., Scholler-Guinard, M., (2004). Carcinogenic properties of proteins with pro-inflammatory activity from Streptococcus infantarius (formerly S.bovis). Carcinogenesis, Vol. 25, No. 8, pp. 1477-1484, 01433334 (Print) 0143-3334 (Linking)

Bisno, A., 12.ed. New York:, (1991). Streptococcal infection. In: Harrison's principles of internal medicine. Harrison, T., Stone, R.s (Eds.), pp. 563-569, McGraw-Hill, New York.

Boleij, A., Schaeps, R.M., de Kleijn, S., Hermans, P.W., Glaser, P., Pancholi, V., Swinkels, D.W., Tjalsma, H., (2009b). Surface-exposed histone-like protein a modulates adherence of Streptococcus gallolyticus to colon adenocarcinoma cells. Infect Immun, Vol. 77, No. 12, pp. 5519-5527, 1098-5522 (Electronic) 0019-9567 (Linking)

Boleij, A., Schaeps, R.M., Tjalsma, H., (2009a). Association between Streptococcus bovis and colon cancer. J Clin Microbiol, Vol. 47, No. 2, pp. 516, 1098-660X (Electronic) 00951137 (Linking)

Bond, J.H., (2005). Colon polyps and cancer. Endoscopy, Vol. 37, No. 3, pp. 208-212, 0013726X (Print) 0013-726X (Linking)

Burnie, J.P., Holland, M., Matthews, R.C., Lees, W., (1987). Role of immunoblotting in the diagnosis of culture negative and enterococcal endocarditis. J Clin Pathol, Vol. 40, No. 10, pp. 1149-1158, 0021-9746 (Print) 0021-9746 (Linking) 
Burns, C.A., McCaughey, R., Lauter, C.B., (1985). The association of Streptococcus bovis fecal carriage and colon neoplasia: possible relationship with polyps and their premalignant potential. Am J Gastroenterol, Vol. 80, No. 1, pp. 42-46, 0002-9270 (Print) 0002-9270 (Linking)

Cutait, R., Mansur, A., Habr-Gama, A., (1988). Endocardite por Streptococcus bovis e pólipos de cólon. Rev Bras Coloproctol, Vol. 8, No. pp. 109-110,

Dai, Y., Wang, W.H., (2006). Non-steroidal anti-inflammatory drugs in prevention of gastric cancer. World J Gastroenterol, Vol. 12, No. 18, pp. 2884-2889, 1007-9327 (Print) 10079327 (Linking)

Darjee, R., Gibb, A.P., (1993). Serological investigation into the association between Streptococcus bovis and colonic cancer. J Clin Pathol, Vol. 46, No. 12, pp. 1116-1119, 0021-9746 (Print) 0021-9746 (Linking)

Devis, A., Dony, A., De Boelpaepe, F., Verhulst, C., Serste, J.P., (1989). [Streptococcus bovis septicemia and colonic cancer]. Acta Chir Belg, Vol. 89, No. 1, pp. 58-60, 0001-5458 (Print) 0001-5458 (Linking)

Devriese, L.A., Vandamme, P., Pot, B., Vanrobaeys, M., Kersters, K., Haesebrouck, F., (1998). Differentiation between Streptococcus gallolyticus strains of human clinical and veterinary origins and Streptococcus bovis strains from the intestinal tracts of ruminants. J Clin Microbiol, Vol. 36, No. 12, pp. 3520-3523, 0095-1137 (Print) 00951137 (Linking)

Dixon, M.F., Genta, R.M., Yardley, J.H., Correa, P., (1996). Classification and grading of gastritis. The updated Sydney System. International Workshop on the Histopathology of Gastritis, Houston 1994. Am J Surg Pathol, Vol. 20, No. 10, pp. 1161-1181, 0147-5185 (Print) 0147-5185 (Linking)

Eisma, R.J., Spiro, J.D., Kreutzer, D.L., (1999). Role of angiogenic factors: coexpression of interleukin- 8 and vascular endothelial growth factor in patients with head and neck squamous carcinoma. Laryngoscope, Vol. 109, No. 5, pp. 687-693, 0023-852X (Print) 0023-852X (Linking)

El-Omar, E.M., (2006). Role of host genes in sporadic gastric cancer. Best Pract Res Clin Gastroenterol, Vol. 20, No. 4, pp. 675-686, 1521-6918 (Print) 1521-6918 (Linking)

Ellmerich, S., Djouder, N., Scholler, M., Klein, J.P., (2000b). Production of cytokines by monocytes, epithelial and endothelial cells activated by Streptococcus bovis. Cytokine, Vol. 12, No. 1, pp. 26-31, 1043-4666 (Print) 1043-4666 (Linking)

Ellmerich, S., Scholler, M., Duranton, B., Gosse, F., Galluser, M., Klein, J.P., Raul, F., (2000a). Promotion of intestinal carcinogenesis by Streptococcus bovis. Carcinogenesis, Vol. 21, No. 4, pp. 753-756, 0143-3334 (Print) 0143-3334 (Linking)

Ernst, P.B., Peura, D.A., Crowe, S.E., (2006). The translation of Helicobacter pylori basic research to patient care. Gastroenterology, Vol. 130, No. 1, pp. 188-206; quiz 212-183, 0016-5085 (Print) 0016-5085 (Linking)

Fagundes, J., Noujain, H., Coy, C., Ayrizono, M., Góes, J., Martinuzzo, W., (2000). Associação entre endocardite bacteriana e neoplasias - relato de 4 casos. Rev Bras Coloproctol, Vol. 20, No. pp. 95-99,

Grinberg, M., Mansur, A., Ferreira, D., Bellotti, G., Pileggi, F., (1990). Endocardite por Streptococcus bovis e neoplasias de cólon e reto. Arq Bras Cardiol, Vol. 67, No. pp. 265-269, 
Groves, C., (1997). Case presentation. The Jhon Hokins Microbiology Newsletter, Vol. 16, No. pp. 42-44,

Gupta, A., Madani, R., Mukhtar, H., (2009). Streptococcus bovis endocarditis; a silent sign for colonic tumour. Colorectal Dis, Vol., No. pp., 1463-1318 (Electronic) 1462-8910 (Linking)

Haqqani, A.S., Sandhu, J.K., Birnboim, H.C., (2000). Expression of interleukin-8 promotes neutrophil infiltration and genetic instability in mutatect tumors. Neoplasia, Vol. 2, No. 6, pp. 561-568, 1522-8002 (Print) 1476-5586 (Linking)

Hirata, Y., Maeda, S., Mitsuno, Y., Akanuma, M., Yamaji, Y., Ogura, K., Yoshida, H., Shiratori, Y., Omata, M., (2001). Helicobacter pylori activates the cyclin D1 gene through mitogen-activated protein kinase pathway in gastric cancer cells. Infect Immun, Vol. 69, No. 6, pp. 3965-3971, 0019-9567 (Print) 0019-9567 (Linking)

Hoen, B., Briancon, S., Delahaye, F., Terhe, V., Etienne, J., Bigard, M.A., Canton, P., (1994). Tumors of the colon increase the risk of developing Streptococcus bovis endocarditis: case-control study. Clin Infect Dis, Vol. 19, No. 2, pp. 361-362, 10584838 (Print) 1058-4838 (Linking)

Hou, L., El-Omar, E.M., Chen, J., Grillo, P., Rabkin, C.S., Baccarelli, A., Yeager, M., Chanock, S.J., Zatonski, W., Sobin, L.H., Lissowska, J., Fraumeni, J.F., Jr., Chow, W.H., (2007). Polymorphisms in Th1-type cell-mediated response genes and risk of gastric cancer. Carcinogenesis, Vol. 28, No. 1, pp. 118-123, 0143-3334 (Print) 0143-3334 (Linking)

Ihler, G.M., (1996). Bartonella bacilliformis: dangerous pathogen slowly emerging from deep background. FEMS Microbiol Lett, Vol. 144, No. 1, pp. 1-11, 0378-1097 (Print) 03781097 (Linking)

Kahveci, A., Ari, E., Arikan, H., Koc, M., Tuglular, S., Ozener, C., (2010). Streptococcus bovis bacteremia related to colon adenoma in a chronic hemodialysis patient. Hemodial Int, Vol. 14, No. 1, pp. 91-93, 1542-4758 (Electronic) 1492-7535 (Linking)

Kaplan, M.H., Chmel, H., Stephens, A., Hsieh, H.C., Tenenbaum, M.J., Rothenberg, I.R., Joachim, G.R., (1983). Humoral reactions in human endocarditis due to Streptococcus bovis: evidence for a common S bovis antigen. J Infect Dis, Vol. 148, No. 2, pp. 266-274, 0022-1899 (Print) 0022-1899 (Linking)

Kargman, S.L., O'Neill, G.P., Vickers, P.J., Evans, J.F., Mancini, J.A., Jothy, S., (1995). Expression of prostaglandin G/H synthase- 1 and -2 protein in human colon cancer. Cancer Res, Vol. 55, No. 12, pp. 2556-2559, 0008-5472 (Print) 0008-5472 (Linking)

Karin, M., Greten, F.R., (2005). NF-kappaB: linking inflammation and immunity to cancer development and progression. Nat Rev Immunol, Vol. 5, No. 10, pp. 749-759, 14741733 (Print) 1474-1733 (Linking)

Kelly, C., Evans, P., Bergmeier, L., Lee, S.F., Progulske-Fox, A., Harris, A.C., Aitken, A., Bleiweis, A.S., Lehner, T., (1989). Sequence analysis of the cloned streptococcal cell surface antigen I/II. FEBS Lett, Vol. 258, No. 1, pp. 127-132, 0014-5793 (Print) 00145793 (Linking)

Klein, R.S., Catalano, M.T., Edberg, S.C., Casey, J.I., Steigbigel, N.H., (1979). Streptococcus bovis septicemia and carcinoma of the colon. Ann Intern Med, Vol. 91, No. 4, pp. 560-562, 0003-4819 (Print) 0003-4819 (Linking) 
Kok, H., Jureen, R., Soon, C.Y., Tey, B.H., (2007). Colon cancer presenting as Streptococcus gallolyticus infective endocarditis. Singapore Med J, Vol. 48, No. 2, pp. e43-45, 00375675 (Print) 0037-5675 (Linking)

Konda, A., Duffy, M.C., (2008). Surveillance of patients at increased risk of colon cancer: inflammatory bowel disease and other conditions. Gastroenterol Clin North Am, Vol. 37, No. 1, pp. 191-213, viii, 0889-8553 (Print) 0889-8553 (Linking)

Lasa, M., Abraham, S.M., Boucheron, C., Saklatvala, J., Clark, A.R., (2002). Dexamethasone causes sustained expression of mitogen-activated protein kinase (MAPK) phosphatase 1 and phosphatase-mediated inhibition of MAPK p38. Mol Cell Biol, Vol. 22, No. 22, pp. 7802-7811, 0270-7306 (Print) 0270-7306 (Linking)

Lee, R.A., Woo, P.C., To, A.P., Lau, S.K., Wong, S.S., Yuen, K.Y., (2003). Geographical difference of disease association in Streptococcus bovis bacteraemia. J Med Microbiol, Vol. 52, No. Pt 10, pp. 903-908, 0022-2615 (Print) 0022-2615 (Linking)

Leport, C., Bure, A., Leport, J., Vilde, J.L., (1987). Incidence of colonic lesions in Streptococcus bovis and enterococcal endocarditis. Lancet, Vol. 1, No. 8535, pp. 748, 0140-6736 (Print) 0140-6736 (Linking)

Leung, W.K., (2006). Helicobacter pylori and gastric neoplasia. Contrib Microbiol, Vol. 13, No. pp. 66-80, 1420-9519 (Print) 1420-9519 (Linking)

Malkin, J., Kimmitt, P.T., Ou, H.Y., Bhasker, P.S., Khare, M., Deng, Z., Stephenson, I., Sosnowski, A.W., Perera, N., Rajakumar, K., (2008). Identification of Streptococcus gallolyticus subsp. macedonicus as the etiological agent in a case of culturenegative multivalve infective endocarditis by $16 \mathrm{~S}$ rDNA PCR analysis of resected valvular tissue. J Heart Valve Dis, Vol. 17, No. 5, pp. 589-592, 0966-8519 (Print) 09668519 (Linking)

Monack, D.M., Mueller, A., Falkow, S., (2004). Persistent bacterial infections: the interface of the pathogen and the host immune system. Nat Rev Microbiol, Vol. 2, No. 9, pp. 747765, 1740-1526 (Print) 1740-1526 (Linking)

Murinello, A., Mendonca, P., Ho, C., Traverse, P., Peres, H., RioTinto, R., Morbey, A., Campos, C., Lazoro, A., Milheiro, A., Arias, M., Oliveira, J., Braz, S., (2006). Streptococcus gallolyticus bacteremia assoaiced with colonic adenmatous polyps. GE-J-Port Gastrentrol Vol. 13, No. pp. 152-156,

Murray, H.W., Roberts, R.B., (1978). Streptococcus bovis bacteremia and underlying gastrointestinal disease. Arch Intern Med, Vol. 138, No. 7, pp. 1097-1099, 0003-9926 (Print) 0003-9926 (Linking)

Murray, P.R., Baron, E.J., (2007). Manual of clinical microbiology (9th). ASM Press, 1555813712 (set) 9781555813710 (set) Washington, D.C.

Nguyen, I., Biarc, J., Pini, A., Gosse, F., Richert, S., Thierse, D., Van Dorsselaer, A., LeizeWagner, E., Raul, F., Klein, J., Scholler-Guinard, M., (2006). Streptococcus infantarius and colonic cancer: Identification and purification of cell wall proteins putatively involved in colorectal inflammation and carcinogenesis in rats. International Congress Series Vol., No. pp. 257- 261,

Nielsen, S.D., Christensen, J.J., Laerkeborg, A., Haunso, S., Knudsen, J.D., (2007). [Molecularbiological methods of diagnosing colon-related Streptococcus bovis endocarditis]. Ugeskr Laeger, Vol. 169, No. 7, pp. 610-611, 1603-6824 (Electronic) 0041-5782 (Linking) 
Norfleet, R.G., Mitchell, P.D., (1993). Streptococcus bovis does not selectively colonize colorectal cancer and polyps. J Clin Gastroenterol, Vol. 17, No. 1, pp. 25-28, 0192-0790 (Print) 0192-0790 (Linking)

Norrby, K., (1996). Interleukin-8 and de novo mammalian angiogenesis. Cell Prolif, Vol. 29, No. 6, pp. 315-323, 0960-7722 (Print) 0960-7722 (Linking)

Ohshima, H., Bartsch, H., (1994). Chronic infections and inflammatory processes as cancer risk factors: possible role of nitric oxide in carcinogenesis. Mutat Res, Vol. 305, No. 2, pp. 253-264, 0027-5107 (Print) 0027-5107 (Linking)

Osawa, R., Fujisawa, T., LI., S., (1995). Streptococcus gallolyticus sp. nov.: gallate degrading organisms formerly assigned to Streptococcus bovis. Syst. Appl. Microbiol., Vol. 18, No. pp. 74-78,

Potter, M.A., Cunliffe, N.A., Smith, M., Miles, R.S., Flapan, A.D., Dunlop, M.G., (1998). A prospective controlled study of the association of Streptococcus bovis with colorectal carcinoma. J Clin Pathol, Vol. 51, No. 6, pp. 473-474, 0021-9746 (Print) 0021-9746 (Linking)

Reynolds, J.G., Silva, E., McCormack, W.M., (1983). Association of Streptococcus bovis bacteremia with bowel disease. J Clin Microbiol, Vol. 17, No. 4, pp. 696-697, 00951137 (Print) 0095-1137 (Linking)

Ruoff, K.L., Miller, S.I., Garner, C.V., Ferraro, M.J., Calderwood, S.B., (1989). Bacteremia with Streptococcus bovis and Streptococcus salivarius: clinical correlates of more accurate identification of isolates. J Clin Microbiol, Vol. 27, No. 2, pp. 305-308, 00951137 (Print) 0095-1137 (Linking)

Schlegel, L., Grimont, F., Ageron, E., Grimont, P.A., Bouvet, A., (2003). Reappraisal of the taxonomy of the Streptococcus bovis/Streptococcus equinus complex and related species: description of Streptococcus gallolyticus subsp. gallolyticus subsp. nov., S. gallolyticus subsp. macedonicus subsp. nov. and S. gallolyticus subsp. pasteurianus subsp. nov. Int J Syst Evol Microbiol, Vol. 53, No. Pt 3, pp. 631-645, 1466-5026 (Print) 1466-5026 (Linking)

Shacter, E., Weitzman, S.A., (2002). Chronic inflammation and cancer. Oncology (Williston Park), Vol. 16, No. 2, pp. 217-226, 229; discussion 230-212, 0890-9091 (Print) 08909091 (Linking)

Sillanpaa, J., Nallapareddy, S.R., Qin, X., Singh, K.V., Muzny, D.M., Kovar, C.L., Nazareth, L.V., Gibbs, R.A., Ferraro, M.J., Steckelberg, J.M., Weinstock, G.M., Murray, B.E., (2009). A collagen-binding adhesin, Acb, and ten other putative MSCRAMM and pilus family proteins of Streptococcus gallolyticus subsp. gallolyticus (Streptococcus bovis Group, biotype I). J Bacteriol, Vol. 191, No. 21, pp. 6643-6653, 1098-5530 (Electronic) 0021-9193 (Linking)

Sillanpaa, J., Nallapareddy, S.R., Singh, K.V., Ferraro, M.J., Murray, B.E., (2008). Adherence characteristics of endocarditis-derived Streptococcus gallolyticus ssp. gallolyticus (Streptococcus bovis biotype I) isolates to host extracellular matrix proteins. FEMS Microbiol Lett, Vol. 289, No. 1, pp. 104-109, 0378-1097 (Print) 0378-1097 (Linking)

Smaali, I., Bachraoui, K., Joulek, A., Selmi, K., Boujnah, M.R., (2008). [Infectious endocarditis secondary to streptococcus bovis revealing adenomatous polyposis coli ]. Tunis Med, Vol. 86, No. 7, pp. 723-724, 0041-4131 (Print) 0041-4131 (Linking) 
Smith, D.G., Lawson, G.H., (2001). Lawsonia intracellularis: getting inside the pathogenesis of proliferative enteropathy. Vet Microbiol, Vol. 82, No. 4, pp. 331-345, 0378-1135 (Print) 0378-1135 (Linking)

Srivastava, S., Verma, M., Henson, D.E., (2001). Biomarkers for early detection of colon cancer. Clin Cancer Res, Vol. 7, No. 5, pp. 1118-1126, 1078-0432 (Print) 1078-0432 (Linking)

Tafte, L., Ruoff, K., (2007). Streptococcus bovis: Answers and Questions. Clin microbial newslett, Vol. 29, No. pp. 49-55,

Teitelbaum, J.E., Triantafyllopoulou, M., (2006). Inflammatory bowel disease and Streptococcus bovis. Dig Dis Sci, Vol. 51, No. 8, pp. 1439-1442, 0163-2116 (Print) 0163-2116 (Linking)

Tjalsma, H., Scholler-Guinard, M., Lasonder, E., Ruers, T.J., Willems, H.L., Swinkels, D.W., (2006). Profiling the humoral immune response in colon cancer patients: diagnostic antigens from Streptococcus bovis. Int J Cancer, Vol. 119, No. 9, pp. 2127-2135, 00207136 (Print) 0020-7136 (Linking)

Travers, P., Rosen, F.S., 1997. Immuno biology bookshelf the comprehensive resource on CD-ROM. Current Biology; Garland Pub., [London ; San Francisco] [New York], pp. 1 CD-ROM.

Vogelmann, R., Amieva, M.R., (2007). The role of bacterial pathogens in cancer. Curr Opin Microbiol, Vol. 10, No. 1, pp. 76-81, 1369-5274 (Print) 1369-5274 (Linking)

Waisberg, J., Matheus Cde, O., Pimenta, J., (2002). Infectious endocarditis from Streptococcus bovis associated with colonic carcinoma: case report and literature review. Arq Gastroenterol, Vol. 39, No. 3, pp. 177-180, 0004-2803 (Print) 0004-2803 (Linking)

Wang, D., Dubois, R.N., (2010). The role of COX-2 in intestinal inflammation and colorectal cancer. Oncogene, Vol. 29, No. 6, pp. 781-788, 1476-5594 (Electronic) 0950-9232 (Linking)

Wentling, G.K., Metzger, P.P., Dozois, E.J., Chua, H.K., Krishna, M., (2006). Unusual bacterial infections and colorectal carcinoma--Streptococcus bovis and Clostridium septicum: report of three cases. Dis Colon Rectum, Vol. 49, No. 8, pp. 1223-1227, 0012-3706 (Print) 0012-3706 (Linking)

Wilson, W.R., Thompson, R.L., Wilkowske, C.J., Washington, J.A., 2nd, Giuliani, E.R., Geraci, J.E., (1981). Short-term therapy for streptococcal infective endocarditis. Combined intramuscular administration of penicillin and streptomycin. JAMA, Vol. 245, No. 4, pp. 360-363, 0098-7484 (Print) 0098-7484 (Linking)

Zarkin, B.A., Lillemoe, K.D., Cameron, J.L., Effron, P.N., Magnuson, T.H., Pitt, H.A., (1990). The triad of Streptococcus bovis bacteremia, colonic pathology, and liver disease. Ann Surg, Vol. 211, No. 6, pp. 786-791; discussion 791-782, 0003-4932 (Print) 00034932 (Linking)

zur Hausen, H., (2006). Streptococcus bovis: causal or incidental involvement in cancer of the colon? Int J Cancer, Vol. 119, No. 9, pp. xi-xii, 0020-7136 (Print) 0020-7136 (Linking) 


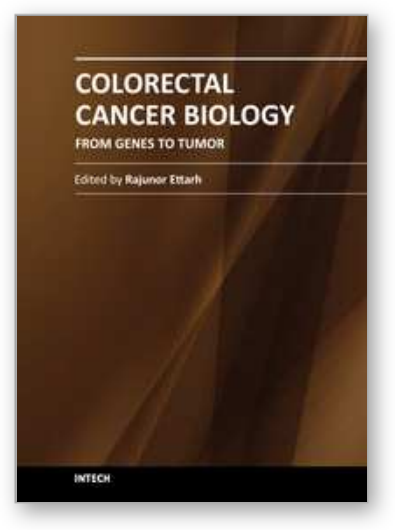

\author{
Colorectal Cancer Biology - From Genes to Tumor \\ Edited by Dr. Rajunor Ettarh
}

ISBN 978-953-51-0062-1

Hard cover, 446 pages

Publisher InTech

Published online 10, February, 2012

Published in print edition February, 2012

Colorectal cancer is a common disease, affecting millions worldwide and represents a global health problem. Effective therapeutic solutions and control measures for the disease will come from the collective research efforts of clinicians and scientists worldwide. This book presents the current status of the strides being made to understand the fundamental scientific basis of colorectal cancer. It provides contributions from scientists, clinicians and investigators from 20 different countries. The four sections of this volume examine the evidence and data in relation to genes and various polymorphisms, tumor microenvironment and infections associated with colorectal cancer. An increasingly better appreciation of the complex inter-connected basic biology of colorectal cancer will translate into effective measures for management and treatment of the disease. Research scientists and investigators as well as clinicians searching for a good understanding of the disease will find this book useful.

\title{
How to reference
}

In order to correctly reference this scholarly work, feel free to copy and paste the following:

A.S. Abdulamir, R.R. Hafidh and F. Abu Bakar (2012). Streptococcus bovis/gallolyticus Induce the Development of Colorectal Cancer, Colorectal Cancer Biology - From Genes to Tumor, Dr. Rajunor Ettarh (Ed.), ISBN: 978-953-51-0062-1, InTech, Available from: http://www.intechopen.com/books/colorectal-cancerbiology-from-genes-to-tumor/streptococcus-bovis-gallolyticus-induce-the-development-of-colorectal-cancer

\section{INTECH}

open science | open minds

\section{InTech Europe}

University Campus STeP Ri

Slavka Krautzeka 83/A

51000 Rijeka, Croatia

Phone: +385 (51) 770447

Fax: +385 (51) 686166

www.intechopen.com

\section{InTech China}

Unit 405, Office Block, Hotel Equatorial Shanghai

No.65, Yan An Road (West), Shanghai, 200040, China

中国上海市延安西路65号上海国际贵都大饭店办公楼 405 单元

Phone: +86-21-62489820

Fax: $+86-21-62489821$ 
(C) 2012 The Author(s). Licensee IntechOpen. This is an open access article distributed under the terms of the Creative Commons Attribution 3.0 License, which permits unrestricted use, distribution, and reproduction in any medium, provided the original work is properly cited. 